\title{
ANALISIS DAN EVALUASI DAMPAK DANA ALOKASI KHUSUS TERHADAP INDIKATOR KINERJA PEMBANGUNAN DI DAERAH STUDI KASUS KABUPATEN-KOTA 2003-2013
}

\author{
Didi Nuryadin, Sri Suharsih \\ Jurusan Ilmu Ekonomi Fakultas Ekonomi UPN Veteran Yogyakarta \\ Email Korespondensi: didinuryadin@gmail.com
}

Naskah Diterima: Januari 2017; Disetujui: April 2017

\begin{abstract}
In the context of financial relations between the central and local governments, the central government has now allocated a Balancing Fund (Dana Perimbangan) to finance local needs in order to support the implementation of decentralization of governance and development as a form of political will to reform and democratize. The aim of this study is to evaluate the effectiveness of DAK allocation for financial year 2003-2013 and to analyze the impact of Dana Alokasi Khusus (DAK) allocation from 2003 to 2013 on various development indicators in the regions (districts / cities). DAK transfer design is the main cause of various issues related to the implementation of DAK. In addition, the problem of DAK allocation mechanisms in the determination of programs and activities, the calculation and use of DAK, budgeting and disbursement of DAK, reporting and monitoring and evaluation of DAK. DAK, as one type of Balancing Fund, has a positive impact on the fiscal capacity of the region, especially the district /city. In addition to regional fiscal capacity, DAK also plays a role in reducing the level of fiscal gap between districts / cities during the period 2003-2007. The result show that DAK allocation (in total) is not significant influence to PDRB per capita of Regency / City. In conclusion, DAK has not had a significant impact on public services and public welfare. This is because the direction of using DAK is not directly used to "build", but only to "maintain". Therefore, DAK is considered not effective enough in an effort to achieve the national priority target.
\end{abstract}

Keywords: balancing fund, decentralization, public welfare

JEL Classifications: H76, H70, I30

Abstrak: Dalam konteks hubungan keuangan antara pusat dan daerah, pemerintah pusat saat ini telah mengalokasikan Dana Perimbangan (DP) untuk membiayai kebutuhan daerah dalam rangka mendukung pelaksanaan desentralisasi pemerintahan dan pembangunan sebagai wujud nyata political will pemerintah untuk melakukan reformasi dan demokratisasi. Tujuan penelitian ini untuk melakukan evaluasi terhadap efektivitas pengalokasian DAK TA 2003-2013 dan menganalisis dampak alokasi DAK 2003 - 2013 terhadap berbagai indikator pembangunan di daerah (Kabupaten/Kota). Desain transfer DAK merupakan permasalahan utama terkait pelaksanaan DAK. Selain itu, permasalahan-permasalahan juga terlihat dalam mekanisme pengalokasian $D A K$, yaitu dalam hal penetapan program dan kegiatan, pengitungan dan penggunaan DAK, penganggaran dan penyaluran DAK, pelaporan dan monitoring serta evaluasi dari DAK. DAK, sebagai salah satu jenis Dana Perimbangan berdampak positif terhadap kemampuan fiskal daerah. Selain terhadap kemampuan fiskal daerah, DAK juga berperan dalam mengurangi tingkat kesenjangan fiskal antar Kabupaten/Kota selama periode tahun 2003-2007. Hasil analisa menunjukkan bahwa alokasi DAK (secara total) tidak signifikan berpengaruh terhadap PDRB per kapita Kabupaten/Kota. Oleh karena itu, dapat disimpulkan bahwa DAK belum memberikan dampak yang signifikan terhadap pelayanan publik dan kesejahteraan masyarakat, karena arah penggunaan DAK belum secara langsung digunakan untuk "membangun", namun hanya untuk "memelihara". Sehingga DAK dinilai belum cukup efektif untuk mencapai sasaran prioritas nasional.

Kata kunci: dana perimbangan, desentralisasi, kesejahteraan masyarakat

Klasifikasi JEL: H76, H70, I30 


\section{PENDAHULUAN}

Dalam konteks hubungan keuangan antara pusat dan daerah, pemerintah pusat saat ini telah mengalokasikan Dana Perimbangan (DP) untuk membiayai kebutuhan daerah dalam rangka mendukung pelaksanaan desentralisasi pemerintahan dan pembangunan sebagai wujud nyata political will pemerintah untuk melakukan reformasi dan demokratisasi. Sesuai dengan Undang-undang Nomor 32 Tahun 2004 tentang Pemerintahan Daerah, Dana Perimbangan dibagi dalam tiga kelompok yaitu Dana Alokasi Umum (DAU), Dana Alokasi Khusus (DAK) dan Dana Bagi Hasil (DBH). Selain Dana Perimbangan, Pemerintah Pusat juga mengalokasikan Dana Otonomi Khusus (Otsus) dan Dana Penyesuaian sebagai komponen Belanja Daerah dalam Anggaran Penerimaan dan Belanja Negara (APBN).

Kebijakan alokasi DAK diberikan sebagai salah satu cara untuk mengakomodasi berbagai kebutuhan prioritas nasional dan merupakan urusan daerah, namun tidak atau belum tertampung dalam formulasi DAU. Oleh karena itu, kebijakan alokasi DAK diprioritas-utamakan untuk membantu daerah dengan kemampuan keuangan di bawah ratarata nasional (dalam hal ini menjadi kriteria umum daerah penerima DAK). Selain itu, kebijakan alokasi DAK juga diprioritaskan untuk menunjang percepatan pembangunan daerah melalui pembangunan sarana dan prasarana di daerah yang berstatus Otonomi Khusus (Otsus) seperti Papua (mencakup Provinsi Papua dan Provinsi Papua Barat), daerah pesisir dan pulau-pulau kecil, daerah perbatasan dengan negara lain, daerah tertinggal/terpencil, daerah rawan banjir/longsor, daerah yang masuk kategori daerah ketahanan pangan dan pariwisata, dan lain-lainnya. Beberapa maksud lain dari alokasi DAK antara lain adalah untuk mendorong penyediaan lapangan kerja, membantu mengurangi jumlah penduduk miskin, dan mendorong pertumbuhan ekonomi daerah. Beberapa prioritas lanjutan (selain kriteria umum) dari alokasi DAK tersebut, biasanya ditetapkan menjadi kriteria khusus dalam alokasi DAK.

Berdasarkan hasil review, kajian, dan fasilitasi di beberapa daerah yang dilakukan oleh Badan Perencanaan Pembangunan Nasional (Bappenas, 2011), pengelolaan DAK selama delapan tahun terakhir (tahun 20032011) masih dihadapkan dengan beberapa permasalahan yang berkaitan dengan aspek keuangan, teknis, kelembagaan, dan tata kelola pemerintahan yang baik (good governance). Dalam aspek keuangan, permasalahan utama adalah belum optimalnya kinerja DAK bagi daerah karena ketidaksesuaian (mismatch) antara besaran alokasi dengan kebutuhan daerah. Dalam aspek teknis, terdapat permasalahan yang berkaitan dengan masih belum optimalnya kebijakan teknis DAK. Sampai saat ini masih belum ada sasaran/target yang jelas, yang ingin dicapai dengan pelaksanaan DAK dalam periode waktu tertentu. Dalam aspek kelembagaan, terdapat permasalahan yang berkaitan dengan belum mantap dan optimalnya koordinasi kelembagaan antara pusat dan daerah, belum terbentuknya tim koordinasi di Pusat dan Provinsi, serta belum optimalnya kinerja tim koordinasi di Kabupaten/Kota. Dalam aspek tata kepemerintahan yang baik (good governance) terdapat permasalahan yang berkaitan dengan masih rendahnya kinerja penerapan prinsip transparansi, akuntabilitas, dan partisipasi dalam pengelolaan DAK. Penyediaan data dan informasi teknis yang diperlukan dalam perhitungan alokasi DAK juga masih lemah.

Sehubungan dengan berbagai permasalahan tersebut maka diperlukan berbagai upaya untuk memperbaiki kualitas seluruh proses, siklus, dan mekanisme pengelolaan DAK sejak dari perumusan kebijakan, perencanaan, penganggaran, pelaksanaan, pemantauan, dan evaluasi. 
Terkait dengan hal tersebut pula, diperlukan evalusai dari dampak alokasi DAK terhadap kinerja perekonomian daerah, terutama kabupaten/kota selama periode tahun 20032013.

\section{METODE PENELITIAN}

Penelitian Analisis dan Evaluasi Dampak DAK terhadap Kinerja Pembangunan Daerah ini dilaksanakan dengan cakupan Pemerintah Daerah seluruh Indonesia, khususnya Pemerintah Daerah Kabupaten/Kota dan selama periode tahun 2003-2013. Monitoring dan evaluasi coba dilakukan terhadap seluruh rangkaian regulasi/kebijakan dan pelaksanaan DAK selama periode tersebut.

Untuk melaksanakan evaluasi secara nasional, dalam penyusunan evaluasi ini akan digunakan data-data sekunder dari berbagai sumber yang berwenang terkait dan juga pelaksanaan desk study/review regulasi dan kebijakan yang terkait dengan pelaksanaan DAK. Desk study/review terhadap berbagai kebijakan dan regulasi yang terkait dengan DAK merupakan kegiatan awal yang perlu dilakukan terlebih dahulu untuk selanjutnya dapat dianalisis lebih lanjut, baik dari sisi konsistensi kebijakan dan regulasi, maupun analisis lebih lanjut melalui analisa dampak dan studi di lapangan. Desk study/review dan observasi diperlukan dalam rangka pelaksanaan monitoring DAK.

Evaluasi secara nasional terhadap keseluruhan Pemerintah Daerah dan setiap bidang nantinya juga dilakukan dengan analisis kuantitatif, yaitu berupa statistik deskriptif dan statistik inferensia (permodelan ekonometrika) untuk mengidentifikasi berbagai hal yang terkait dengan pengalokasian DAK, karakteristik wilayah, dampak dari pengalokasian DAK, dan tujuantujuan dari pelaksanaan DAK. Model ekonometrik yang feasible digunakan adalah model cross-section untuk analisis per tahun dan per bidang.
Tahapan selanjutnya dari penelitian Analisis dan Evaluasi Dampak Alokasi DAK adalah menganalisis hasil, manfaat, dan dampak dari pengalokasian DAK terhadap daerah selama periode tahun tahun 2003- 2013. Analisa dilakukan dengan menggunakan metode statistik deskriptif dan kuantitatif, yaitu permodelan ekonometrika untuk menelah dampak DAK secara makro.

Dengan melihat bidang-bidang pengalokasian DAK, indikator arah penggunaan alokasi DAK, dan indikator kinerja Pemerintah Daerah, yang akan diterapkan untuk seluruh daerah (dalam hal ini Kabupaten/Kota) dan karena jumlah Kabupaten/Kota mengalami perubahan dari waktu ke waktu selama periode tahun 20032013, maka model ekonometrika yang tepat digunakan adalah model analisa regresi crosssection (kerat-lintang) yang dilakukan untuk setiap tahun dan setiap bidang.

Model umum yang digunakan untuk menganalisa dampak langsung dari alokasi DAK pada setiap bidang dan setiap tahun adalah:

$$
Y_{r}=f\left(D_{A K}, X_{1 r}, X_{2 r}, \ldots \ldots .\right)
$$

Dimana:

$\mathrm{Y}_{\mathrm{r}}$ : Indikator arah penggunaan DAK di suatu bidang di suatu daerah

DAK $_{\mathrm{r}}$ : Alokasi DAK di suatu bidang di suatu daerah

$\mathrm{X}_{1 \mathrm{r}}, \mathrm{X}_{2} \mathrm{r} \ldots$ : Variabel variabel lain yang diduga ikut mempengaruhi $\mathrm{Yr}$

r : Daerah

Hampir sama dengan model di atas, model umum yang digunakan untuk mengalisa dampak tidak langsung dari alokasi DAK pada setiap bidang dan setiap tahun adalah:

$$
Z_{r}=f\left(D A K_{r}, W 1 r, W 2 r, \ldots .\right)
$$

dimana:

$\mathrm{Z}_{\mathrm{r}} \quad$ : Indikator kinerja Pemerintah Daerah sesuai bidang yang terkait di suatu daerah

DAKr $_{\mathrm{r}}$ : Alokasi DAK di suatu bidang di suatu 
daerah

$$
\begin{array}{ll}
\text { W1r }, & \text { W2r, ....: Variabel-variabel lain yang } \\
& \text { diduga ikut mempengaruhi } \mathrm{Zr} \\
\mathrm{r} & \text { : Daerah }
\end{array}
$$

Metode analisis yang dilakukan menggunakan data panel, yakni gabungan data runtut waktu (times series) dan cross section sampel Kabupaten/Kota di Indonesia.

\section{Evaluasi Dampak DAK terhadap Kinerja Pemerintah Daerah}

Alokasi DAK dari waktu ke waktu mengalami peningkatan secara nyata dari waktu ke waktu, baik berdasarkan nilai total alokasi, jumlah bidang alokasi, jumlah daerah penerima, dan rata-rata nilainya per daerah penerimanya. Alokasi DAK yang mengalami peningkatan tersebut sebagian besar merupakan alokasi Dak yang ditujukan untuk Kabupaten/Kota. Sementara itu, alokasi DAK untuk Provinsi relatif kecil dibandingkan alokasi DAK untuk Kabupaten/Kota dan tidak konsisten dari waktu ke waktu. Oleh karena itu, nantinya analisa dampak nantinya difokuskan pada analisa dampak DAK di Kabupaten/Kota terhadap kondisi fiskal daerah Kabupaten/Kota dan analisa dampak DAK di Kabupaten/kota terhadap kinerja infrastruktur Kabupaten/kota menurut bidang alokasi DAK. Secara umum, temuan-temuan penting (key findings) dari analisis regulasi dan kebijakan DAK dapat dibagi dalam empat kelompok besar yaitu:

a. Belum terlihat adanya konsistensi, kesinkronisasian, dan kesinergian antar regulasi dan kebijakan terkait DAK;

b. Adanya ketidaktepatan dalam desain teknis dan keuangan DAK meliputi alokasi, kebutuhan, penggunaan (bidang) dan sasaran (wilayah) terkait dengan kriteria pengalokasian DAK;

c. Masih terlihat banyaknya kelemahan dalam pengaturan administrasi dan kelembagaan meliputi perencanaan, koordinasi, pelaksanaan, pelaporan, dan pemantauan pelaksanaan DAK; dan

d. Rendahnya aspek good governance, meliputi transparansi, partisipasi, dan akuntabilitas kegiatan-kegiatan dalam pelaksanaan DAK.

Sementara itu, beberapa hal utama dalam menganalisa dampak dari DAK dengan menggunakan model ekonometrika adalah:

- Model ekonometrika yang digunakan adalah Model Analisa Cross Section

- Terkait dengan ketersediaan data, data variabel dampak yang digunakan adalah data kabupaten/kota pada tahun 2002 (kondisi awal) sampai dengan 2005 (kondisi akhir) dan analisa dampak yang dapat dilakukan juga tidak seluruhnya seperti dalam bidang alokasi DAK, dan juga, data DAK yang digunakan adalah Data DAK tahun 2003 sampai dengan 2005

- Karena modelnya adalah Cross Section, maka data yang digunakan adalah data perubahan dari kondisi tahun 2002 (kondisi awal) sampai tahun 2005 (kondisi akhir)

- Untuk mengatasi permasalahan penambahan observasi Kabupaten/Kota akibat pemekaran, dilakukan penyesuaian dengan kondisi data tahun 2002 menjadi 363 Kabupaten/Kota dan pengunaan dummy variable untuk pemekaran

- Analisa dampak langsung yang dilakukan mencakup bidang pendidikan, kesehatan, dan infratsruktur (jalan dan irigasi)

- Analisa dampak tidak langsung dilakukan terhadap PDRB per Kapita

- Variabel penjelas tambahan berupa karakteristik daerah diwujudkan dalam bentuk dummy variable

Sementara itu, untuk model ekonoemtrika, fungsi umumnnya adalah sebegai berikut:

1. Analisa Dampak Langsung: $\mathrm{Yk}=\mathrm{f}(\mathrm{DAKk}, \mathrm{DAKTOT}-\mathrm{DAKk}, \mathrm{PAD}, \mathrm{DAU}$, BHP, BHBP, LLPS, DKK, DJB, DMEKAR)

2. Analisa Dampak Tidak Langsung: PDRBKAP $=\mathrm{f}($ DAKTOT, PAD, DAU, BHP, BHBP, LLPS, DKK, DJB, DMEKAR), Dimana: 
- Yk :Indikator Kinerja Bidang k (terkait arah penggunaan DAK)

- DAKk : Alokasi DAK di Bidang k

- DAKTOT: Total Alokasi DAK (seluruh bidang)

- PAD

:Pendapatan

Asli

Daerah

- DAU

- BHP

- BHBP

- LLPS yang sah

- DKK

: Dana Alokasi Umum

: Bagi Hasil Pajak

:Bagi Hasil Bukan Pajak

: Lain-lain Pendapatan

Kota (Kabupaten $=0$, Kota $=1$ )

- DJB : Dummy Jawa-

Bali (Kabupaten/Kota di Luar JawaBali=0, di Jawa-Bali=1)

- DMEKAR : Dummy Pemekaran (Kabupaten/Kota Non- Dimekarkan=0,

- Dimekarkan=1)

Indikator-indikator yang digunakan dalam pengolahan model ekonometrika untuk analisa dampak dari DAK adalah:

a. Indikator Pendidikan:

Perubahan Jumlah SD Negeri dan Perubahan Jarak Desa ke SD

b. Indikator Kesehatan:

Perubahan jumlah puskesmas, perubahan jumlah puskesmas pembantu, perubahan jarak desa ke puskesmas, dan perubahan Jarak Desa ke Puskesmas Pembantu

c. Indikator Infrastruktur Jalan:

Rasio panjang jalan mantap terhadap panjang jalan total, dan perubahan jumlah desa berjalan aspal

d. Indikator Infrastruktur Irigasi:

Perubahan lahan sawah beririgasi

e. Indikator Kesejahteraan

Rata-rata PDRB per kapita atas dasar harga konstan

Dengan menggunakan kerangka model ekonometrika dan indikator-indikator tersebut, dan dikarenakan penggunaan DAK yang sesuai degan PMK/KMK dan Juknis adalah umumnya untuk pemeliharaan rutin, pemeliharaan berkala, dan peningkatan/pembangunan skala kecil, maka analisa kuantitatif dampak DAK terhadap kinerja infrastruktur menurut bidang alokasi DAK diperkirakan akan mengalami bias. Hal tersebut dibuktikan dengan contoh penggunaan alokasi DAK bidang infrastruktur di Departemen Pekerjaan Umum (PU) selama periode tahun 2003-2007. Walaupun demikian, analisa kuantitatif dampak DAK terhadap kinerja infrastruktur menurut bidang alokasi DAK dengan menggunakan model ekonometrika tetap digunakan untuk membuktikan kebenaran perkiraan tersebut.

Mengapa tidak mengubah kerangka indikator yang digunakan dalam pengolahan model ekonometrika untuk analisa dampak dari DAK? Hal tersebut dikarenakan keterbatasan ketersediaan dari data yang ada terkait dengan kualitas infrastruktur. Data tersebut sangat jarang tersedia, dan apabilapun tersedia, umumnya data tersebut tidak lengkap antar daerahnya dan berbeda antar tahun serta dalam kondisi yang tidak up-date.

Hasil pengolahan analisa dampak DAK dengan menggunakan model ekonometrika secara lengkap dan rinci dapat dilihat dalam Lampiran tulisan ini. Secara umum, hasil dari pengolahan dampak DAK dengan menggunakan model ekonometrika adalah:

- Hasil analisa dampak langsung menunjukkan pengaruh (beberapa ada yang positif, dan juga negatif) yang tidak signifikan dari alokasi dari alokasi DAK di masing-masing bidang terhadap indikator masing-masing bidang;

- Analisa dampak tidak langsung menunjukkan juga bahwa alokasi DAK (secara total) tidak signifikan berpengaruh terhadap PDRB per kapita Kabupaten/Kota; dan

- Secara umum, dapat disimpulkan bahwa DAK, baik menurut alokasi bidang maupun secara total, belum memberikan dampak yang signifikan terhadap pelayanan publik dan kesejahteraan masyarakat.

Hasil yang menunjukkan tidak 
signifikannya pengaruh DAK terhadap kinerja pelayanan publik dan kesejahteraan, terjadi dimungkinkan disebabkan oleh:

- Kurang baiknya manajemen pengelolaan DAK;

- Ketidaktepatan alokasi DAK, baik menurut wilayah, besaran, maupun arah penggunaannya di masing-masing bidang alokasi;

- Tidak fokusnya pengalokasian DAK pada fungsi-fungsi utama, terutama fungsi dari pemerintahan sendiri;

- Relatif kecilnya nilai alokasi DAK; dan atau

- Penggunaan DAK bukan ditujukan untuk mencapai indikator-indikator tersebut (yang digunakan sebagai variabel terikat (dependent variable).

\section{SIMPULAN}

Beberapa kesimpulan yang dapat diambil dari pelaksanaan evaluasi ini antara lain adalah:

- Design transfer DAK merupakan akar permasalahan utama dari berbagai permasalahan terkait pelaksanaan DAK. Hal tersebut terlihat dari permasalahan baik dalam aspek aspek regulasi dan kebijakan, aspek teknis dan keuangan, aspek administrasi dan kelembagaan, maupun dalam aspek tata kelola. Selain itu, permasalahan-permasalahan juga terlihat dalam mekanisme pengalokasian DAK, yaitu dalam hal penetapan program dan kegiatan, pengitungan dan penggunaan DAK, penganggaran dan penyaluran DAK, dan pelaporan serta monitoring dan evaluasi dari DAK;

- DAK, sebagai salah satu jenis Dana Perimbangan, berdampak positif terhadap kemampuan fiskal daerah, khususnya Kabupaten/Kota. Dampak tersebut terlihat dari proporsi DAK terhadap pendapatan dan belanja dalam APBD seluruh Kabupaten/Kota yang meningkat. Selain terhadap kemampuan fiskal daerah, DAK juga berperan dalam mengurangi tingkat kesenjangan fiskal antar Kabupaten/Kota selama periode tahun 2003-2007;

- Hasil analisa dampak langsung menunjukkan pengaruh (beberapa ada yang positif, dan juga negatif) yang tidak signifikan dari alokasi dari alokasi DAK di masing-masing bidang terhadap indikator masing-masing bidang. Analisa dampak tidak langsung menunjukkan juga bahwa alokasi DAK (secara total) tidak signifikan berpengaruh terhadap PDRB per kapita Kabupaten/Kota. Oleh karena itu, secara umum, dapat disimpulkan bahwa DAK, baik menurut alokasi bidang maupun secara total, belum memberikan dampak yang signifikan terhadap pelayanan publik dan kesejahteraan masyarakat. Hal ini dikarenakan memang arah penggunaan DAK yang memang tidak atau belum secara langsung digunakan untuk "membangun", namun hanya untuk "memelihara". Oleh karena itu, DAK dirasa belum cukup efektif dalam upaya mencapai sasaran prioritas nasional yang menjadi bagian dari urusan daerah; dan

- Dari sisi kualitas, manfaat dan dampak di masing-masing bidang dapat dikatakan hasil kegiatan DAK dalam persepsi responden adalah 'baik'. Hal ini ditunjukkan oleh proporsi yang cukup besar untuk dua pilihan skala tertinggi. Namun dari sisi kecukupan kuantitas, distribusi jawaban lebih 'ke kiri' (kurang dan cukup memadai). Hasil ini mengindikasikan bahwa masyarakat (yang diwakili penerima manfaat di 6 daerah sampel): membutuhkan dan merasakan manfaat kegiatan DAK di masing-masing bidang dan hal ini selaras dengan perilaku konsumsi atas barang publik (extensive consumption). Namun, hasil ini juga perlu catatan khusus, yakni sangat dimungkinkan responden tidak memiliki cukup informasi untuk memilah apakah kegiatan tersebut 
didanai oleh DAK atau yang lain (APBD). Dengan kata lain, esensi pelaksanaan DAK dirasakan cukup bermanfaat bagi daerah, walaupun belum secara jelas keefektifannya, khususnya masyarakat di sekitar lokasi pelaksanaan kegiatan DAK.

Beberapa rekomendasi kebijakan yang dapat diberikan dari hasil pelaksanaan analisis dan evaluasi DAK ini antara lain adalah:

- Prioritas nasional perlu ditentukan target dan sasarannya secara jelas, yang bila didasarkan atas optimalitas ekonomi sebagai satu kesatuan, fungsi perencanaan ekonomi nasional perlu dimantapkan sebagai landasan penentuan prioritas. Dalam konteks ini salah satu kegiatan ialah melakukan klassifikasi spasial barang dan pelayanan publik, untuk melengkapi yang sekarang tertulis dalam Undangundang Nomor 32 Tahun 2004. Dengan tegas orang dapat mengambil kesimpulan bahwa memang jumlah barang publik nasional akan meningkat dari yang ada dalam Undang-undang tadi. Proyek DAK hendaknya merupakan turunan dari prioritas yang seyogyanya telah termasuk dalam RKP. Secara materil prioritas nasional hendaknya merupakan bagian dari yang secara hakiki termasuk dalam barang publik nasional, tetapi secara faktual masuk dalam urusan daerah.

- Memfokuskan ulang ("refocusing") bidang penerima DAK. Secara umum, DAK berfokus pada bidang infrastruktur (jalan, irigasi, dan air bersih) dan kesra (pendidikan dan kesehatan). Namun seiring waktu, fokus ini nampak mengalami pergeseran. Fokus pada bidang Kesra nampak semakin menguat, namun fokus pada bidang infrastruktur justru semakin memudar. Ke depan, dibutuhkan fokus ulang dan pembatasan bidang yang akan mendapatkan alokasi DAK. Upaya "refocusing" lain yang relevan adalah dengan mempercepat pengalihan Dana
Dekonsentrasi dan Tugas Pembantuan menjadi DAK. Potensi DAK sebagai salah satu sumber pembiayaan pembangunan infrastruktur di tingkat lokal dapat ditingkatkan secara signifikan dengan mempercepat pengalihan Dana Dekonsentrasi dan Tugas Pembantuan menjadi DAK ini. Akomodasi kebijakan "refocusing" DAK ini membutuhkan kebijakan lain yang mengikutinya seperti kerangka anggaran jangka menengah (MTEF/Mid-Term Expedinture Framework), "earmarking" untuk pembangunan infrastruktur dari semua peningkatan penerimaan pajak daerah maupun transfer dari pusat, serta kerangka pendanaan lain seperti melalui obligasi daerah dan perbaikan efisiensi belanja publik di tingkat lokal.

- Perlu ada penegasan tentang pasal 162 dalam Undang-undang Nomor 3 Tahun 2004 di mana daerah diberi peluang mengajukan usulan proyek yang didanai DAK. Walaupun secara de facto praktek usulan daerah, baik disampaikan melalui saluran lembaga legislatif ataupun departemen teknis atau cara lain, penegasan ini perlu ditetapkan sebab Undang -undang Nomor 33 Tahun 2004 pasal 39 tidak mencantumkannya, apalagi tidak menyentuh adanya peran provinsi dalam pengusulan kegiatan DAK.

- Penyederhanaan kriteria dan mekanisme serta fleksibilitas dari alokasi DAK. Termasuk dalam hal ini tentang penghindaran adanya perbedaan persepsi dari program DAK seperti pada butir terdahulu. Screening proyek seharusnya berada di pusat tetapi daerah telah mengetahui kriteria pemilihan sehingga merupakan bagian dari transparansi dari proses alokasi. Sistem demikian akan sekaligus mengurangi persepsi berlakunya favoritism dalam alokasi tersebut. 


\section{DAFTAR PUSTAKA}

Badan Perencanaan Pembangunan Nasional, 2006, Pengelolaan Dana Alokasi Khusus, Bappenas, Jakarta.

Badan Perencanaan Pembangunan Nasional, 2006, Pengolahan dan Analisis Laporan Monitoring Pelaksanaan Dana Alokasi Khusus, Bappenas, Jakarta.

Badan Pusat Statistik, 2003, Data Hasil Statistik Potensi Desa (PODES) Tahun 2002, BPS, Jakarta.

Badan Pusat Statistik, 2007, PDRB Kabupaten/Kota tahun 2000-2006, BPS, Jakarta.

Badan Pusat Statistik, 2007, PDRB ProvinsiProvinsi di Indonesia Menurut Lapangan Usaha tahun 2000-2006, BPS, Jakarta.

Badan Pusat Statistik, 2006, Data Hasil Statistik Potensi Desa (PODES) Tahun 2005, BPS, Jakarta.

Bird, Richard, M. dan Vailancourt, F. 2000, Desentralisasi Fiskal di Negara-Negara Berkembang, PT Gramedia Pustaka Utama, Jakarta.

Brodjonegoro, Bambang P.S., 2006, Desentralisasi sebagai Kebijakan Fundamental untuk Mendorong Pertumbuhan Ekonomi Nasional dan Mengurangi Kesenjangan Antardaerah di Indonesia, Pidato pada Upacara Pengukuhan Sebagai Guru Besar Tetap dalam Bidang Ilmu Ekonomi, Fakultas Ekonomi Universitas Indonesia, 18 Maret 2006, Depok.

Departemen Keuangan RI, Direktorat Jenderal Perimbangan Keuangan, 2007, Pengaliahan Dana Dekonsentrasi dan Tugas Pembantuan Menjadi DAK, materi presentasi pada Workshop Pengalihan Dana Dekonsentrasi dan Tugas Pembantuan Menjadi DAK di Hotel Quality Jakarta, 28 Agustus 2007, Jakarta.

Departemen Keuangan RI, Direktorat Jenderal Perimbangan Keuangan, 2008, Data
APBD dan Dana Perimbangan Tahun 2001-2007, Departemen Keuangan Jakarta.

Departemen Keuangan RI, 2007, Indonesia's Budget Statistics 2002-2008, Departemen Keuangan RI, Jakarta.

Departemen Pekerjaan Umum, Direktorat Jenderal Bina Marga, 2007, Pengelolaan Dana Dekonsentrasi dan Dana Tugas Per(m)bantuan Bidang Infrastruktur Sub Bidang Jalan, materi presentasi pada Workshop Pengalihan Dana Dekonsentrasi dan Tugas Pembantuan Menjadi DAK di Hotel Quality Jakarta, 28 Agustus 2007, Jakarta.

Departemen Pendidikan Nasional RI, Direktorat Jenderal Manajemen Dikdasmen, 2007, Pengelolaan Dana Dekonsentrasi dan Tugas Pembantuan, materi presentasi pada Workshop Pengalihan Dana Dekonsentrasi dan Tugas Pembantuan Menjadi DAK di Hotel Quality Jakarta, 28 Agustus 2007, Jakarta.

Djohermansyah, 2005, Pembagian Kewenangan Antar Pemerintah, Pemerintah Propinsi, dan Pemerintah Kabupaten/Kota, makalah disampaikan dalam Semiloka Evaluasi Kebijakan Dana Dekonsentrasi, Hotel Borobudur, 2-3 Juni 2005, Departemen Keuangan RI, Jakarta.

Kementerian PPN/Bappenas, Deputi Bidang Pengembangan Regional dan Otonomi Daerah, 2007, Dana Dekonsentrasi dan Dana Tugas Pembantuan: Konsep, Isu, $\mathcal{E}$ Agenda, materi presentasi pada Workshop Pengalihan Dana Dekonsentrasi dan Tugas Pembantuan Menjadi DAK di Hotel Quality Jakarta, 28 Agustus 2007, Jakarta.

Kuncoro, M., 2004, Otonomi Daerah: Reformasi, Perencanaan, Strategi dan Peluang, Jakarta: Penerbit Erlangga.

Lembaga Penelitian SMERU, 2007, Mekanisme dan Penggunaan DAK, SMERU, Jakarta.

Pemerintah Republik Indonesia, 2004, Undang- 
Undang No. 32/2004 tentang

Pemerintahan Daerah,

www.indonesia.go.id, diunduh 13

September 2015.

Pemerintah Republik Indonesia, 2004, UndangUndang No. 33/2004 tentang Perimbangan

Keuangan Pemerintah Pusat dan

Pemerintah Daerah,

www.indonesia.go.id, diunduh 13

September 2015.

Pemerintah Republik Indonesia, 2005, Peraturan Pemerintah No. 55/2005

tentang Dana Perimbangan,
www.indonesia.go.id, diunduh 13 Mei 2016.

Pemerintah Republik Indonesia, 2007, Peraturan Pemerintah No. 38/2007 tentang Pembagian Urusan Pemerintahan antara Pemerintah, Pemerintahan Provinsi, dan Pemerintahan Kabupaten/Kota, www.indonesia.go.id, diunduh 13 Mei 2016.

Richardson, Harry W., 1978, Urban Economics, The Drydes Press, Hinsdale, Illinois, USA.

Sidik, M. 2002, "Format Hubungan Keuangan Pemerintah Pusat dan Daerah yang Mengacu Pada Pencapaian Tujuan Nasional", makalah Seminar Nasional: Public Sector Scrorecard. 17-18 April 2002, DJPKPD RI, Jakarta.

Simanjuntak, Robert A., 2002, Transfer Pusat ke Daerah: Konsep dan Praktik di Beberapa Negara dalam Machfud Sidik $d k k$. (eds.)," Dana Alokasi Umum (DAU): Konsep, Hambatan, dan Prospek di Era Otonomi Daerah". Jakarta: Penerbit Buku Kompas. 